\title{
Autoimmune and autoinflammatory mechanisms in uveitis
}

\author{
Richard W. Lee • Lindsay B. Nicholson • H. Nida Sen • \\ Chi-Chao Chan • Lai Wei • Robert B. Nussenblatt • \\ Andrew D. Dick
}

Received: 5 February 2014 / Accepted: 13 April 2014 / Published online: 24 May 2014

(C) The Author(s) 2014. This article is published with open access at Springerlink.com

\begin{abstract}
The eye, as currently viewed, is neither immunologically ignorant nor sequestered from the systemic environment. The eye utilises distinct immunoregulatory mechanisms to preserve tissue and cellular function in the face of immunemediated insult; clinically, inflammation following such an insult is termed uveitis. The intra-ocular inflammation in uveitis may be clinically obvious as a result of infection (e.g. toxoplasma, herpes), but in the main infection, if any, remains covert. We now recognise that healthy tissues including the retina have regulatory mechanisms imparted by control of myeloid cells through receptors (e.g. CD200R) and soluble inhibitory factors (e.g. alpha-MSH), regulation of the blood retinal barrier, and active immune surveillance. Once homoeostasis has been disrupted and inflammation ensues, the mechanisms to regulate inflammation, including $\mathrm{T}$ cell apoptosis, generation of $\mathrm{T}_{\text {reg }}$ cells, and myeloid cell suppression in situ, are less successful. Why inflammation becomes persistent remains unknown, but extrapolating from animal
\end{abstract}

This article is a contribution to the special issue on Mechanisms of Tissue Injury in Autoimmune Diseases - Guest Editor: Dan Eilat

\section{R. W. Lee • A. D. Dick}

National Institute for Health Research Biomedical Research Centre at Moorfields Eye Hospital NHS Foundation Trust and UCL Institute of Ophthalmology, University Hospitals Bristol NHS, Foundation

Trust, and University of Bristol, Bristol, UK

R. W. Lee $・$ L. B. Nicholson· A. D. Dick $(\triangle)$

School of Clinical Sciences, University of Bristol, Bristol Eye

Hospital, Low Maudlin Street, Bristol BS1 2LX, UK

e-mail: a.dick@bristol.ac.uk

H. N. Sen · C.-C. Chan $\cdot$ L. Wei $\cdot$ R. B. Nussenblatt Laboratory of Immunology, National Eye Institute, National Institutes of Health, Bethesda, MD, USA

\section{Wei}

State Key Laboratory of Ophthalmology, Zhongshan Ophthalmic Center, Sun Yat-sen University, Guangzhou, China models, possibilities include differential trafficking of $\mathrm{T}$ cells from the retina, residency of $\mathrm{CD}^{+} \mathrm{T}$ cells, and alterations of myeloid cell phenotype and function. Translating lessons learned from animal models to humans has been helped by system biology approaches and informatics, which suggest that diseased animals and people share similar changes in $\mathrm{T}$ cell phenotypes and monocyte function to date. Together the data infer a possible cryptic infectious drive in uveitis that unlocks and drives persistent autoimmune responses, or promotes further innate immune responses. Thus there may be many mechanisms in common with those observed in autoinflammatory disorders.

Keywords Uveitis · Autoimmunity · Autoinflammation · Macrophages $\cdot \mathrm{T}$ lymphocytes $\cdot$ Immunotherapy

\section{Overview of uveitis: clinical and standard concepts}

Survival depends on the pivotal sense of vision. Many pathologies affect vision and the eye, and almost all involve the immune response at some level. The function of the immune system in the eye is critical; correspondingly, there are active mechanisms in place to preserve immune homeostasis. When these are disrupted, frank inflammation ensues, which is clinically manifest as uveitis.

Uveitis is defined as inflammation of the vascular uveal tract of the eye, including the iris, ciliary body, and choroid; however, adjacent structures such as the retina, optic nerve, vitreous, and sclera may also be affected. Therefore, in practice any intraocular inflammation involving compromise of the blood ocular barrier is considered to be in the same group of disorders. Clinically, uveitis is classified anatomically as anterior, intermediate, posterior, or panuveitis, depending on which anatomical structures of the eye are involved [1]. All these forms are characterised by an inflammatory cellular 
infiltrate, which ophthalmologists visualize directly in an office setting using a biomicroscope. The anterior chamber of the eye is filled with optically clear aqueous fluid, allowing the practitioner to clearly see infiltrating leukocytes that are counted and scored in accordance with standardized grading systems [1]. This also applies to vitreous gel, which occupies the posterior segment of the eye.

Protein exudates can result in an opacification of the usually clear ocular media, which is graded as flare in the aqueous or haze in the vitreous (Fig. 1a). Retinal and choroidal abnormalities are often localized, with clear foci of vascular inflammation or tissue infiltration (Fig. 1b). This clinical assessment is routinely augmented by ancillary tests such as fluorescein and indocyanine green angiography (Fig. 1c), which help determine the level of inflammatory activity in the retinal and choroidal tissues and consequent need for therapy. Recent advances in imaging technologies are now also generating high-resolution assessments in vivo of the retina in uveitic patients that approach histological clarity (Fig. 1d).

In 2010, WHO estimated that 285 million people were visually impaired; of these, 39 million were blind, and approximately $10 \%$ was due to uveitis [2]. In the USA and Europe, uveitis accounts for $10-20 \%$ of severe visual handicaps, and up to $10 \%$ of blindness, in working age adults [3-7]. Uveitis may be caused by infections and/or autoimmunity. The relative proportion of causation is highlighted by geography; uveitis related to autoimmune disease is more common in developed countries, whilst overt infectious disease causes are more frequent in the developing world. Approximately $70-90 \%$ of sight-threatening uveitis in developed countries is reported to be non-infectious [4, 8].

Non-infectious uveitis comprises a heterogeneous group of disorders diagnosed based on their clinical characteristics, which may be either confined to the eye or present together with systemic symptoms. Salient examples include birdshot chorioretinopathy (BCR), characterised by multiple small inflammatory lesions distributed throughout the retina and choroid (Fig. 1e); BCR's association with the retinal protein Santigen is well established [3,9]. Although recent reports have demonstrated a systemic immune deviation in BCR [10, 11], clinically BCR is an isolated ocular pathology. In contrast, sarcoidosis and Behcet's-associated uveitis and ankylosing spondylitis have clear systemic manifestations.

The clinical phenotype of non-infectious intraocular inflammation is replicated in experimental animal models that are driven by immune responses to self-antigen [12] The animal models support a role for autoimmunity, albeit experimentally inflammation is often shaped by the presence of mycobacterial protein. However, unlike other classical systemic autoimmune disorders, there are no clearly defined serological markers to assist diagnosis (e.g. autoantibodies) within majority of uveitis entities, except high HLA association (HLA-A29 and Birdshot chorioretinopathy). Nor are there markers in clinical use, predictive of either severity or prognosis. Nonetheless, 25 to $30 \%$ of uveitis is associated with systemic autoimmune or autoinflammatory disease [4, 5], as described above.

To recapitulate uveitis in animals, the most commonly used model is experimental autoimmune uveoretintis (EAU) [13]. Although originally described in Guinea pig, intraocular inflammation may be induced in both rat and mouse. Disease model susceptibility is dependent upon strain and in turn MHC haplotype (e.g. H-2k mice). In particular in rats, the Lewis strain delivers a very susceptible aggressive monophasic disease and the mouse (H-2) on both B10 or BL/6 backgrounds and display after an acute response a chronic persistent disease. Traditionally, EAU has been induced via active immunisation with retinal antigens emulsified in complete Freund's adjuvant. More recently, mouse models of spontaneous disease have been achieved by transgenic expression of retinal proteins (RBP-3) or neoantigens (HEL) with or without TCR transgenic T cells, or with human HLA [14-16]. The clinical features and pathology of these animal models bear remarkable similarity between some human conditions and mouse [17].

\section{Systemic versus local immune responses}

Traditionally, uveitis has been categorized as either infectious or non-infectious, and there are obvious examples of each. That said, it is likely that both may co-exist. The immune response to an infection leads to a number of different possible outcomes. Uncontrolled immunity and/or unrestrained infection can lead to death. The successful elimination of a pathogen commonly leads to immune memory, but between these poles, infections may persist. Such chronic infections may either be controlled locally $[18,19]$ or lead to exhaustion of the immune response $[20,21]$. These different outcomes illustrate a plastic component to immunosurveillance, with the potential for immune responses to adapt in response to alterations in the environment. In the context of autoimmunity, where autoantigen cannot be completely eliminated, the immune response may resemble that seen in persistent infection.

These dynamic considerations are relevant within the affected tissue as well as the systemic circulation. In the eye, this is especially pertinent because of the immune privileged nature of the tissue. Flowing from the seminal work of Medawar [22], the limited ability of tissues such as the eye and brain to reject non-MHC-matched transplants defined immune privilege. Historically, immune privilege was often interpreted as a lack of immunosurveillance. This absolute view is no longer appropriate [23-25]; instead, we recognise that immune cells visit healthy sites of immune privilege [26, 27]. Autoimmune diseases such as multiple sclerosis within these tissues radically alter the local dynamics of immune cell trafficking within the affected tissue [28]. The resulting remodelling may put the eye at risk of non-specific immune activation, 

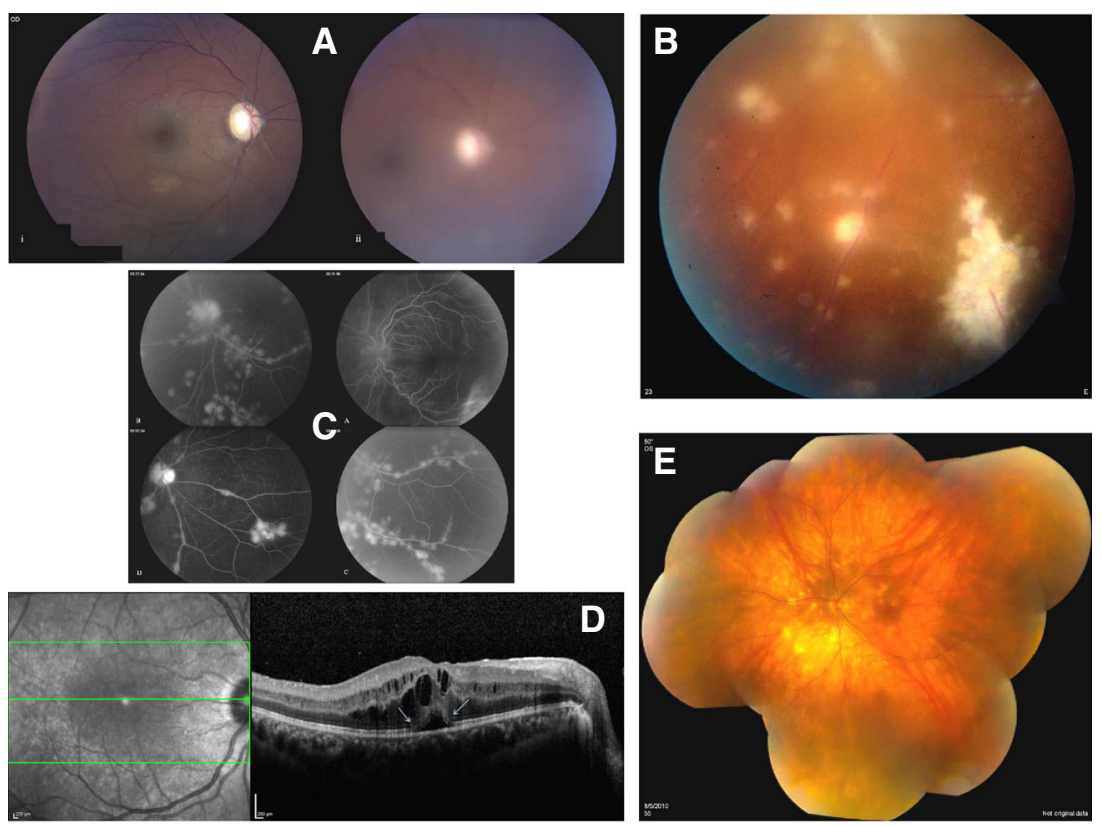

Fig. 1 Diagnostic imaging depicting manifestations of uveitis. a Vitreous haze seen in the right eye of a 39-year-old African American female with sarcoidosis associated panuveitis $(i$, left panel) clears following treatment (ii, right panel). Please note that the borders of optic nerve and details of retinal vasculature are not clearly visible due to vitreous haze. b Peripheral fundus photographs of an African American male with neurosarcoidosis and panuveitis show significant perivascular exudates and chorioretinal granulomas. c Fluorescein angiogram of the same patient in b shows no staining in the very early phase but diffuse involvement of the entire retinal vasculature with staining of the exudates

precipitating clinical relapse; in humans, uveitis relapse has been associated with intercurrent infection [29].

In retina following inflammation, the ensuing rebalancing of immunosurveillance encompasses many immune cell types, including the well-established $\mathrm{CD}^{+}$and $\mathrm{CD} 11 \mathrm{~b}^{+}$effector populations as well as NK cells, $\mathrm{CD}^{+}$cells, and $\mathrm{B}$ cells (J. Boldison, unpublished data). The importance of innate lymphoid cells in the eye is not yet known. The recent discovery that a population of $\mathrm{CD} 3^{+} \mathrm{CD} 4^{-} \mathrm{CD} 8^{-}$cells is both necessary and sufficient to recapitulate a model of the pathology of spondyloarthropathy [30] highlights the potential for small subpopulations of cells to organise local tissue inflammation. One relevant issue then is the fate of the lymphoid cells that are recruited to the eye. It is well established that during an immune response to a self-limiting pathogen, the majority of effector cells are eliminated from the systemic pool as the infection resolves [31]. Data in EAE models indicate that large numbers of $\mathrm{CD}^{+} \mathrm{T}$ effector cells die by apoptosis within the inflamed tissue [32, 33]; however, T cells may also traffic out of affected tissues, including the eye. This possibility is supported by our data that shows that treatment that arrests trafficking leads to a very rapid fall in the cell content of the eye $[34,35]$. This result is consistent with a model in which immune cells exit the eye, as well as die in situ. In addition, studies evaluating other tissues such as the in early-mid phase (upper right and lower left panels) and leakage in late phase (lower right panel) is evident. d Spectral domain optical coherence tomography (SD OCT) of a 28 -year-old Hispanic male with noninfectious uveitis and cystoid macular edema shows intra retinal cysts as well as subretinal fluid (arrows). Please note the detailed visibility of different retinal layers and the disruption of outer segment (ellipsoid) layer in the area of subretinal fluid (arrow). e Fundus photograph of the left eye of a 58-year-old Caucasian female with Birdshot chorioretinopathy shows multiple, deep, yellowish choroidal lesions scattered in the posterior pole, particularly nasal to the optic nerve

brain, lung, and gut [36-40] established that some effector cell populations (in these cases, $\mathrm{CD} 8^{+}$cells) take up long-term residence in tissues following infection. We have found this to be the case in EAU (J. Boldison and L. Nicholson, unpublished data), where infiltrating $\mathrm{CD} 8^{+}$cells of different phenotypes also show different patterns of migration. The expression of CD69, well-known as a marker of T cell activation, has more recently been associated with long-lived $\mathrm{CD} 8^{+}$tissue resident cell populations, whilst CD69-negative cells may recirculate more readily (Ref. [21] and J. Boldsion and L. Nicholson, unpublished data). The full spectra of mechanisms that regulate this process remain poorly understood. Stem cell niches which have been defined in bone marrow may be a useful corollary here. Complex interactions may be critical to maintaining these environments, where many different cell types can regulate niches both directly and indirectly, and where hematopoietic stem cell traffic in and out of the niches is reported [41].

\section{The role of $T$ cells in driving adaptive immunity in the eye}

The eye is affected by both autoinflammatory and autoimmune disease processes. Advances defining the molecular pathology of autoinflammatory conditions have led to an 
appreciation of the wide range of diseases in which inflammation is driven by genetic mutations affecting elements of the innate immune system. These conditions embrace a spectrum that is initiated by aberrant inflammation, but then includes adaptive immune elements [42]. The archetype for this type of autoinflammatory process in the eye is Blau syndrome, caused by gain-of-function mutations in the NOD2 gene that lead to increased basal nuclear factor $\mathrm{kB}(\mathrm{NF} \kappa \mathrm{B})$ transcriptional activation [43]. Patients present with early-onset granulomatous inflammation, skin rash, and camptodactyly. The lesions in the retina have a distinct and characteristic appearance, whilst an immunohistochemical analysis of skin and other peripheral granulomas reveals an abundance of $\mathrm{CD} 4^{+}$ lymphocytes and $\mathrm{CD} 68^{+}$monocyte-macrophage lineage cells; there are fewer $\mathrm{CD}^{+}$lymphocytes, but large amounts of IFN- $\gamma$, IL-17, and IL-6 [44]. This example demonstrates that innate activation can lead to the involvement of adaptive immune cells in this autoinflammatory process, and illustrates the complexity that accompanies uncontrolled chronic immune activation.

Idiopathic autoimmunity arises following the activation and expansion of retinal antigen-specific $\mathrm{T}$ lymphocytes. Experimentally, the triggering event can happen at sites distant to the affected organ, although whether this occurs in human disease is rarely known. The dominant paradigm is that of a $\mathrm{CD}^{+} \mathrm{T}$ helper cell-driven process. The relevance of this to human disease is supported by the association of sympathetic ophthalmia and Vogt-Koyanagi-Harada disease with specific HLA class II alleles [45, 46], as well as the identification of ocular antigen-responsive $\mathrm{T}$ cells in both the peripheral blood and eyes of patients [47, 48]. The strong MHC association with autoimmunity arises both through the need for specific autoantigen presentation [49] and through the selection of a potentially pathogenic $\mathrm{T}$ cell repertoire [50].

Once potentially pathogenic $\mathrm{T}$ cells have been produced in the periphery, access to the immune privileged ocular environment may be under the control of vessel-associated antigen presentation, in a fashion analogous to that described in the brain [51]. But with their translation from blood vessels to tissue, local activation of antigen-responsive $\mathrm{T}$ cells provide the necessary signals that focus autoimmunity to the eye. Later, the same signals are also crucial for the activation of regulatory cells that limit the pathology due to inflammation within tissues.

When naive $\mathrm{CD}^{+} \mathrm{T}$ helper cells are activated, they reorganise transcriptional networks [52]. This leads them to assume different functional phenotypes, often characterised by the secretion of signature cytokines [53, 54]. Of the many genes that are regulated by this process, those that influence expression of chemokine receptors and subsequent patterns of tissue localisation are also important mediators of effector function. In rodent models of uveitis, immunisation with whole proteins or peptides induces a $\mathrm{CD} 4^{+} \mathrm{T}$ cell-dependent uveitis [55-57]. Studies using the transfer of $\mathrm{CD} 4^{+} \mathrm{T}$ cell lines and clones have confirmed that these cells are sufficient to initiate the autoimmune process in a number of different models [58-61]. By differentiating murine $\mathrm{T}$ cells in vitro and transferring them to naive hosts, the pathological potential of different $\mathrm{T}$ cell phenotypes has been evaluated [62]. In EAU, such studies identify both Th1 and Th17 T helper cells as important inducers of autoimmune disease [63]. When $\mathrm{CD}^{+}{ }^{+} \mathrm{T}$ cells were purified from the retinas of animals with uveitis that was induced by peripheral immunisation, and then studied ex vivo, both Th1 and Th17 cells were found. The relative proportions of these populations change over time [28]. Cytokines produced by these cells condition the local microenvironment, and activate macrophages (especially IFN- $\gamma$ produced by Th1 cells), recruit neutrophils, and potentially restructure the local environment (e.g. through IL-17 produced from Th17 cells; [64]). Differentiated T cell subpopulations also have a role in controlling local inflammation when they acquire a $\mathrm{T}$ regulatory phenotype. The normal ocular microenvironment favours differentiation to Foxp $3^{+}$ regulatory $\mathrm{T}$ cells, but when the eye is already inflamed this is not the case [59].

Although $\mathrm{CD}^{+} \mathrm{T}$ cell-driven disease is the dominant paradigm in models of uveitis, studies have shown that it is possible to induce autoimmunity within the eye using antigen-specific $\mathrm{CD}^{+} \mathrm{T}$ cells [65]. Further, it has long been recognised that $\mathrm{CD} 8^{+} \mathrm{T}$ cell numbers increase during the course of experimental uveitis [57, 66]. As with Blau syndrome, a condition whose clinical ocular features manifest more with time, uveitis is the result of much more than the aberrant activation of a single cell type. For both $\mathrm{CD} 4^{+}$and $\mathrm{CD} 8^{+}$lymphocytes, their role within the tissue may change as disease progresses. In the EAU model, increasing evidence suggests there is persistent dysregulation of immunosurveillance of the retina following the induction of disease $[67,68]$. These changes are a manifestation of the defining feature of the immune system: its ability to adapt to reduce the impact of subsequent infections after an initial encounter with a pathogen. From this perspective, it is informative to consider new data relating to the development of memory to viruses. Following infection, $\mathrm{CD} 8^{+}$memory populations take up long-term residence in tissues and adapt to those environments differently compared to residing in the lymphoid compartment. They then play an important role when tissues are re-challenged with the same infection $[21,37,39]$.

The role of $\mathrm{CD}^{+}$and $\mathrm{CD} 8^{+}$lymphocytes in uveitis may therefore go well beyond the initiation of tissue destruction, and include the regulation of immunosurveillance of the local microenvironment by controlling the flow of cells in and out of the tissue. Regulating cell trafficking would limit local activation of recently recruited autopathogenic cells, whilst maintaining a local presence of $\mathrm{CD} 8^{+}$cells primed to respond to increases in antigen presentation. 


\section{Control of myeloid cell function in the eye is influenced by tissue and cellular environment}

The retina and choroid are furnished with a rich network of myeloid cells that create and establish immune tissue tone, and maintain immune health of these tissues [69]. This is especially pertinent when considering the function of the fragile neural retina, which evolved as a pivotal part of vision necessary for survival. The tight control of myeloid cell activation in the retina permits a continual survey of the environment, maintenance of scavenger function, and prevention of unwanted cellular and tissue damage. Whilst there are no data on the time course and extent of the inflammatory cell infiltrate during ocular disease in humans, results of studies in mice emphasize a predominance and persistence of macrophages throughout disease [28, 68]. The frequently cited 'granulomatous' uveitis (which heralds a clinical feature, not a pathological definition) illustrates the notion that there are large numbers of infiltrating inflammatory cells that aggregate and persist throughout course of disease, even after the acute phase of inflammation. This idea is further supported by studies of pathology in humans, and by interrogation of animal models that demonstrates discrete myeloid, macrophage, and $\mathrm{T}$ cell accumulations in later disease [17].

The dispute as to whether microglia contributes to onset of ocular inflammation [70] has to be balanced against their homeostatic role in maintaining a healthy retina, where the data is more compelling [71]. Microglia are networked throughout the retina, and display regulatory phenotypes and functions consistent with other tissue-resident macrophages elsewhere in the body [69] (Fig. 2). Thus, the tissue may set an activation threshold to prevent unwanted damage. For example, myeloid activation is controlled via cognate-receptor interactions, principally CD200R and its ligand, CD200; CD200 is expressed on neurons and endothelium [76-80]. Loss of receptor or ligand produced by genetically manipulating mice, or by blocking interactions in rats, results in an activated macrophage phenotype (NOS2-positive); following insult (either autoimmune or injury), a more aggressive disease phenotype results [72, 81]. Myeloid regulation can be reconstituted via ligation of receptor (e.g. by treatment with anti-CD200R monoclonal antibodies or by treatment with $\mathrm{CD} 200 \mathrm{Fc}$ ), which ablates and controls autoimmune retinal inflammation in EAU [73] and reduces consequences of injury [82]. This interpretation is supported further by similar observations in CNS [79]. Myeloid regulation operates in humans as well as mouse, and extends to control of mast cells and other tissue sites such as lung [83-87].

Overall, tissue damage in EAU is significantly attenuated when macrophages are removed $[88,89]$ or myeloid activation is blocked [90-92]. In EAU, compelling evidence indicates IFN $\gamma$-mediated macrophage activation that depends on TNF- $\alpha$ and functional TNFR1 results in high levels of nitric oxide, TNF- $\alpha$, and IL-6. These mediators, in turn, generate lipid peroxidation and damage surrounding cells [93-96]. Experimentally, we consistently observe that the tissue is protected following neutralisation of TNF- $\alpha$ activity, or by reprogramming myeloid cell activation threshold with CD200R treatment. Not surprisingly, therefore, anti-TNF- $\alpha$ agents provide clinical benefit in human disease ([97-99], and see below).

Thus, the pivotal drive to tissue damage is via activation of the non-specific myeloid compartment. But even though classical IFN- $\gamma$-mediated macrophage activation is apparent, myeloid suppressor cell phenotypes that control $\mathrm{T}$ cell proliferation and targets have been observed. Such control is mediated through myeloid endoprostanoid receptors and nitric oxide $[100,101]$. The critical balance of these responses serves to self-regulate via suppression of $\mathrm{T}$ cell function in situ and to clear danger; but tissue damage may result when this balance is not fully achieved.

A principal observation in murine EAU is the persistence of inflammation [102, 103], implying that the threshold of myeloid activation is not reset and homeostasis is not restored. In the presence of persistent $\mathrm{T}$ cell responses [28], the tissue remains vulnerable. A constant macrophage infiltrate remains, although in nearly all models the macrophages exhibit an alternative activation phenotype in later stages (as opposed to the earlier classical activation phenotype; [67]) that may be secondary to tissue remodelling. One result of a chronic immune cell infiltrate is persistent tissue remodelling contemporaneous with myeloid activation, of which one hall mark is angiogenesis. The angiogenic response during persistent tissue immune cell infiltrate requires an operative CCL2-CCR2 axis, but is also influenced by multifunctional matrix proteins, such as thrombospondin-1 (TSP-1) [67]. Subverting the angiogenic response (but without altering the initial inflammation and antigen-specific targeting of tissue) by knocking out matricellular proteins such as TSP-1 results as expected persistent disease (as observed in wild-type mice [104]) but notably results in increased angiogenesis (a detriment to retinal function as observed in neovascular diseases such as diabetic retinopathy and age-related macular degeneration). Moreover, macrophages secrete TSP-1 following TLR ligation; however, T cell activation regulates TSP-1: both Th1 and Th2 cytokines increase threshold for TLRmediated TSP-1 production, and in their presence, less is secreted [100]. Together the results infer that there is matricellular control (e.g. TSP) of macrophage activation in terms of remodelling and angiogenesis during $\mathrm{T}$ cell mediated responses and whilst initial disease severity is not altered with loss of TSP, regulating tissue remodelling, (as determined by extent of angiogenesis) is perturbed. 


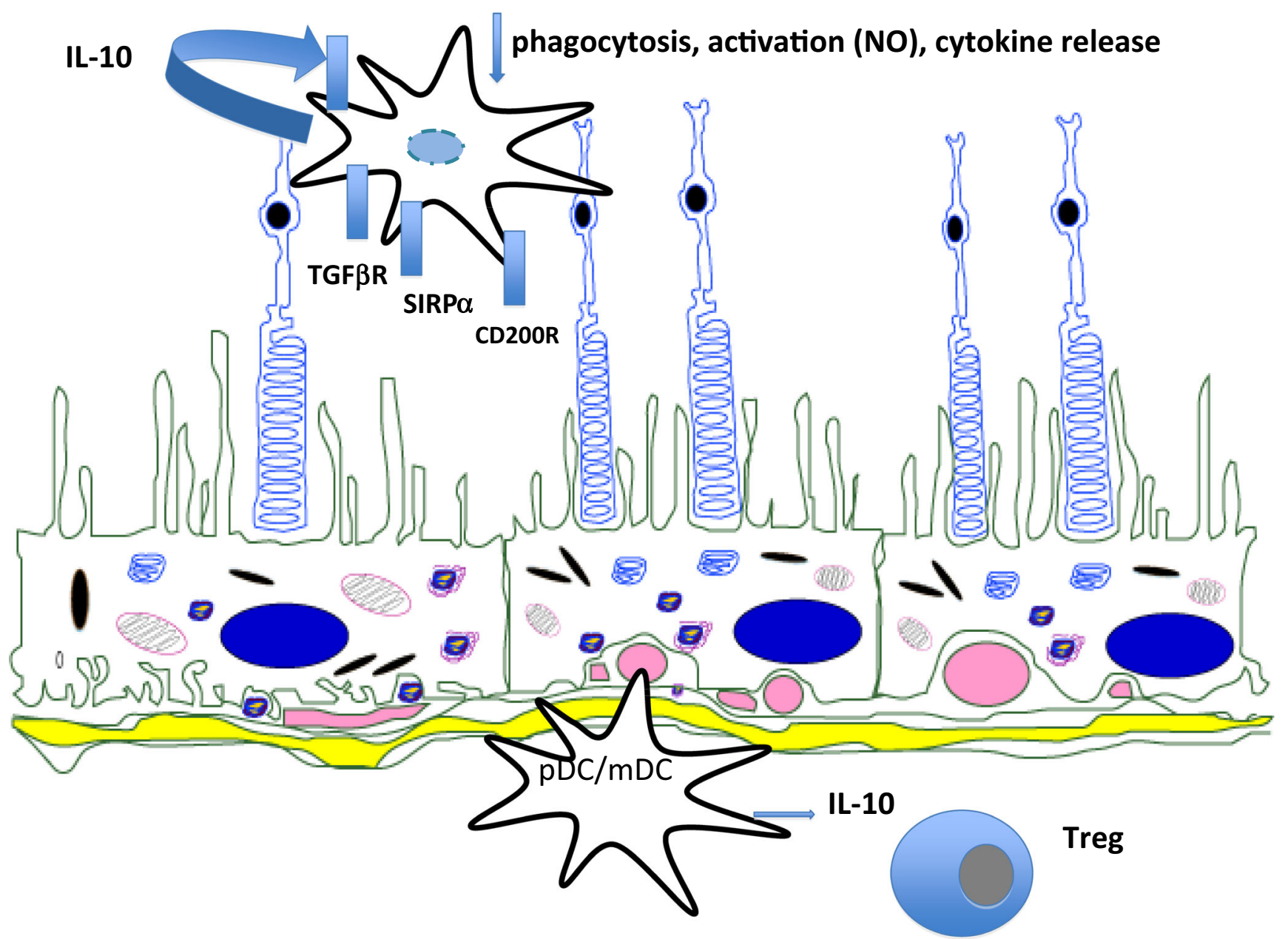

Fig. 2 Regulation and setting of the threshold of myeloid cell responses within the retina and choroid. Microglia and choroidal myeloid cells (dendritic cells and macrophages) sense the environment and regulate inflammatory responses. The healthy tissue sets the threshold for response through inhibitory receptors (e.g. CD200R, SIRP $\alpha$ ) or via the TGF- $\beta$ rich environment. The regulation via neuronal cognate interaction

Controlling the macrophage response certainly is a tractable therapeutic goal, as illustrated by the success of antiTNF- $\alpha$ agents clinically. The ability of macrophages to respond to environmental, cytokine, and receptor signals provides adaptability in controlling inflammation and in restoring structure and function. Translation will remain challenging (given the plasticity of myeloid cells and how rapidly they adapt) when considering timing of treatment. In EAU there are other compounding influences to consider for therapy. For example, complement is activated during disease; whilst arguably not critical to development of inflammation [105, 106], suppressing or regulating complement diminishes EAU expression [107, 108]. The presumed mechanism of action is at the level of suppressing macrophage activation. Similarly, chemokine gradient support or perturbation can suppress or exacerbate EAU disease, where the myeloid compartments are being manipulated [109-113]. is augmented by the regulatory functions of RPE, via mediators such as PD- 1 and PD-L1 interactions, TGF- $\beta$ secretion, and inhibitory peptides. The response to activation of myeloid cells is dominated by IL-10 release; whilst other pro-inflammatory cytokines are also produced, the default response is downregulation [71-75]

\section{Current understanding of pathology in humans, and future opportunities}

Much of our understanding concerning the underlying pathology of ocular inflammatory disease has come from various animal models. Observations in humans have supported some, but not all, of the various mechanisms noted in animal studies, mostly pertaining to autoimmunity. However, globally infection remains a significant cause of uveitis. Infections can actively invade ocular tissue and result in an inflammatory process. These include toxoplasmosis, tuberculosis, syphilis, leprosy, and tularemia, as well as DNA viruses such as CMV, VZV, and HSV [114] with other possible pathogens emerging [115]. With some exceptions, the clinical evaluation of most patients in developed countries who are evaluated for an anterior uveitis will not demonstrate direct invasion of a pathogen into the ocular tissues. In most cases, aqueous 
samples taken from the front of the eye during active inflammation have shown inflammatory infiltrates, including T cells, B cells, and macrophages. Analyses of such samples also suggest active immune regulatory mechanisms, including FasLigand-induced $\mathrm{T}$ cell apoptosis and cortisol regulation of dendritic cell function [116-118]. However, an important issue is what initiates these inflammatory processes within the eye. Despite the absence of evidence of overt infection, experimental data suggest a central role for bacterial products. Anterior uveitis can be induced by injecting endotoxin (lipopolysaccharide) subcutaneously, intravenously, or intraperitoneally at a site far from the globe of the eye $[119,120]$. A number of other bacterial products, including MDP (murinyl dipeptide), also have the capacity to induce an ocular inflammatory response [121]. These observations implicate innate immune activation and inflammasome activation via NOD [122]. In addition, $30 \%$ of ankylosing spondylitis (AS) patients will have an anterior uveitis episode [123]. AS is associated with asymptomatic Crohn's disease, a disorder in which bacterial products are strongly implicated [124]. It is quite possible that bacterial fragments act as adjuvants, activating the innate immune response and perhaps secondarily the adaptive immune system.

The types of immune cells in the eye and the cytokines they produce have been studied in intermediate and posterior uveitis. Proinflammatory cytokines such as IFN- $\gamma$, TNF- $\alpha$, IL-1, IL-2, and IL- 6 have all been reported in the eye during inflammation [125]. In other ocular conditions, such as Behcet's disease, there may be an increase in cytokines such as TGF- $\beta$. Elevated IL-17 levels have been reported circulating in the blood of sarcoidosis patients [126, 127], and elevated levels of both IL-17 and IL-23 have been reported in BCR patients undergoing cataract extraction [10]. Immune responses have been further characterised in several other human disorders, either by evaluation of chorioretinal biopsies or by studying eyes removed for various reasons [128]. Chorioretinal biopsies, i.e. removing the choroid and retina together, are not performed routinely but have yielded much information, often helping in the choice of therapeutic options. Whilst $\mathrm{T}$ cells (including various subsets) predominate in the infiltrates, other inflammatory cells including B cells and macrophages have been identified. Studies of enucleated or post mortem eyes from uveitis patients have indicated upregulation of adhesion molecule expression on the retinal vessels, provided evidence of apoptosis of retinal cells after severe inflammation [129]. As noted above for EAU animal models, human tissue studies have also suggested a switch of macrophage subtypes in the retina of eyes from a classically activated to an alternatively activated phenotype [130].

In general, patients with uveitis exhibit a diversity of systemic immune responses. Microarray studies performed on the blood of uveitis patients demonstrated many different genotypic signatures, even amongst patients with the same clinical diagnosis [131]. To date, however, in vivo examination of the living eye, particularly the posterior pole, that would permit identification of immune cells is lacking.

One can only speculate as to the triggering mechanisms that lead to severe ocular inflammatory disease. Indeed, they may be multifactorial. This is clear from the immune profiling, which demonstrated at least four immune signatures [131]. Overt infection may not be the major force but it is reasonable to hypothesize a role for microbes acting as initiating or potentiating factors. In some cases, viral infections that have been cleared may have initiated immune responses that are then propagated by molecular mimicry (i.e. cross reactions with antigens found in the eye). Evidence of anamnestic responses to ocular antigens, particularly the retinal Santigen, has been reported by many, in patients with both infectious and non-infectious processes in the eye [132]. A more subtle way in which microbes may be playing a role is their adjuvant effect, i.e. by shifting the balance from immune responses that are normally controlled by the immune system's downregulatory mechanisms to ones that instead lead to overt disease. Two conceptual ideas may therefore be important in the development of uveitis. The first is the hypothesis that patients prone to developing an intraocular inflammatory response are those whose immune system has undergone a 'loosening' of the normal oversight of the immune system, as seen in immunosenescence. The second is that these changes may be very important in preventing or reversing the normally positive effects of parainflammation.

\section{Systems biology approach}

It is apparent that uveitis is a complex disease involving multiple organs, often beyond the eye. The classical approaches to studying the pathogenesis of diseases, by focusing one or two candidate genes, have limited success in identifying disease-specific biomarkers, elucidating the complex molecular mechanism underlying uveitic disorders, and improving the clinical management of these sight-threatening diseases. The recent development of many high dimensional assays has allowed large-scale enumeration and quantification of millions to billions of endpoints [133]. Together with available computational/ bioinformatic tools that manage, analyse, and integrate biological data, a comprehensive view of biological phenomena and disease process may be elucidated [134]. Despite extensive application of systems biology approaches in studying inflammatory diseases such as rheumatoid arthritis and multiple sclerosis, to date only a limited number of studies have investigated uveitis with high-throughput approaches.

Over the last decade, genome-wide association studies (GWAS) have been extensively used to identify disease- 
associated genetic variants in large patient cohorts [135]. The genetic risk of Behcet's disease, amongst all uveitic disorders, has been well studied [136]. Using single-nucleotide polymorphism (SNP) arrays, Fei et al. [137] performed the first GWAS study of BD in 2009. In 2010, Remmers et al. [138] and Mizuki et al. [139] identified the MHC class I, IL23RIL12R $\beta 2$, and IL-10 loci as the major genetic risk factors in Behcet's disease, using large patient and control cohorts from Turkey and Japan, respectively. Furthermore, more recent GWAS studies have elucidated many new genetic susceptibility loci, including CCR1, STAT4, KLRC4, CD40, HLA$\mathrm{B} * 51$, and ERAP1 [102, 140-142]. Interestingly, many of the risk loci found in Behcet's disease were shared with ankylosing spondylitis, psoriasis, and inflammatory bowel disease [143-147].

In addition to genetic susceptibility, the regulation of gene expression according to the environmental cues is also crucial in physiological and pathological conditions. Using DNA microarray technology, Usui et al. [148] revealed elevated expression of ICOS in Behcet's disease. However, a genome-wide expression profiling study carried out by $\mathrm{Li}$ et al. suggested that rather diverse gene expression signatures exist amongst noninfectious uveitis patients [131].

Identification of globally dysregulated proteins in systemic and local inflammatory diseases became possible recently with a significant advance of technologies such as mass spectrometry, multi-parameter flow cytometry, and protein arrays [149]. Both ocular fluids and serum proteins from patients with Behcet's disease [150, 151] and Vogt-Koyanagi-Harada disease [152] have been surveyed in multiple studies using mass spectrometry-based technologies. However, it is unclear how these proteins are related to intraocular inflammation and disease pathology. In addition, recent studies have demonstrated that data from single-cell-based analyses of peripheral blood cells using multiparameter flow cytometry can distinguish BD from sarcoidosis diseases, suggesting a broad application of high-dimensional proteomic datasets in uveitis diagnosis [153].

Obviously, systems biology approaches are rapidly generating large amounts of information on genomes, epigenomes, transcriptomes, and proteomes. However, appropriate bioinformatic tools for high-throughput data analysis are still needed [149]. Although novel biomarkers and targets that are amenable to drug development may potentially be identified by these global unbiased approaches, extensive validation is still warranted. With the utilization of game-changing technologies such as high-throughput sequencing technologies [154] and cytometry by time-of-flight [155] in clinical service, we expect that this multidisciplinary approach will accelerate biomarker discovery and drug development for uveitis.

\section{Targeting therapies for specific responses: perspectives and conclusions}

Much knowledge has accrued through interrogating immunopathological processes in animal models of uveitis, with results that eloquently illuminate specific targets. As discussed, overall the models have demonstrated pivotal role for TNF- $\alpha$, as well as activated CD4 T cells, their signature cytokines, and their ability to influence trafficking of cells. Approaches based on this body of knowledge are currently in early-phase, randomised controlled trials to treat uveitis. Alongside such developments, there are new therapeutic avenues to consider, some of which are common to many inflammatory diseases. First, autoimmune responses may be suppressed, i.e. by tolerance therapies [74, 156-159]. Second, specific T cell responses may be suppressed directly [160-162], or indirectly by suppressing antigen presentation or augmenting regulatory T cell responses $[163,164]$. Third, non-specific tissue damaging responses may be disarmed by inhibiting macrophage function $[72,73,82]$, by inhibiting cytokines [97-99, 165, $166]$, and by inhibiting trafficking of cells [34, 35, 167].

Whilst experimental results suggest reasons to hope, the limited clinical success to date is somewhat discouraging. Nonetheless, clinical outcomes raise important questions. How can outcomes be predicted? What are the major immunopathogenic drivers for each disease entity within spectrum of uveitis? How will patients respond to any given therapy? Close examination suggests very good evidence for success of anti-TNF- $\alpha$ agents in Behcet's disease [166, 168-174] and other uveitides [99, 175]. Such results are encouraging in terms of translating findings in animal models to people. However, failures and gaps in our knowledge remain. For example, to date therapies have not been targeted to individuals. Trials are typically designed based on what are probably single types of uveitic disorders, but the subjects enrolled are likely to represent a heterogeneous group of disorders, all of which are grouped under the umbrella term uveitis. With the current lack of detailed understanding of separate clinical entities, it may be difficult to deliver and detect significant therapeutic responses. The experience with anti-IL-17 therapy is a case in point. Both animal models [176-180] and human observations [181, 182] clearly supported the logic of targeting this cytokine, particularly in Behcet's disease. But the results of three trials using anti-IL17 treatments [183] had no evidence for positive effects, and were disappointing. These results support increasing evidence inferring that the pathological mechanisms at play in Behcet's disease are autoinflammatory, rather than autoimmune. That said, given that the studies did not attempt to match disease phenotypes with IL-17 biomarker expression, the trials did highlight the necessity of aligning treatments to the patient, and using biomarkers to target treatments to patients that are more likely to respond. Similarly, it is important to optimise 
the timing of treatment in disease evolution, as well as dose and route of administration of treatment. In the future, this may include combinatorial approaches. When knowledge of targets is optimal, success may become more evident, as we have appreciated from treating the spectrum of autoinflammatory conditions. For example, initial efforts to apply anti-TNF- $\alpha$ therapies in uveitis associated with Juvenile systemic granulomatous disease (Blau's disease) [184-186] or anti-IL-1RA therapies in CINCA-NOMID [187] have been successful.

As discussed throughout, the challenge faced at the point of clinical presentation with many of the uveitides is the likelihood that they represent a spectrum of autoimmune conditions. These may be dominated by $\mathrm{T}$ cells or by antibodies, and/or reflect both autoimmune and autoinflammatory processes that drive innate responses. If largely driven by autoantibodies or B cells, or where vasculitis is predominant, then anti-CD20 therapy may be appropriate; indeed, in the right patients the therapeutic effect of anti-CD20 treatment with rituximab has been substantial [188-190].

Thus, there is a need to refine therapies for individual patients, and hopefully predict response prior to administration. Whilst there may well be common effector mechanisms in uveitis, such mechanisms remain influenced by epigenetic regulation or by inflammatory gene polymorphisms, skewing predicted drug effects [191-194]. Nonetheless, we can make progress. For example, in the current therapeutic paradigm of treating with corticosteroids prior to using steroid-sparing agents or specific biologic therapies, maximizing response rates requires us to address a common problem: up to $40 \%$ of patients do not respond to corticosteroids. Corticosteroid resistance lies in part within the Th17 T cell population [195]. Such knowledge may facilitate our ability to target therapies designed to overcome the lack of steroid responsiveness at the time of presentation, and restore treatment responses in these patients [196-198].

Furthermore, advancing knowledge suggests opportunities to consider therapies that combine treatments and routes, i.e. by delivering one treatment to the eye alongside systemic delivery of another. For example, gene therapy might be used within the retina [199], whilst the systemic immune response is modulated simultaneously, such as via tolerance induction, by preventing cell trafficking, or by specifically neutralising cytokine or signalling pathways. Such strategies, which could be refined and targeted by taking advantage of appropriate biomarkers, could have the net effect of restoring immune health and homeostasis to the retina.

Acknowledgements This work was partly supported by the National Institute for Health Research (NIHR) Biomedical Research Centre based at Moorfields Eye Hospital NHS Foundation Trust and UCL Institute of Ophthalmology. The views expressed are those of the author(s) (R.W.L., A.D.D.) and not necessarily those of the NHS, the NIHR or the Department of Health. L.W. was supported by the National Basic Research
Program of China (2013CB967002). Karen L. Elkins provided additional scientific writing and editing during the preparation of the manuscript.

Open Access This article is distributed under the terms of the Creative Commons Attribution License which permits any use, distribution, and reproduction in any medium, provided the original author(s) and the source are credited.

\section{References}

1. Jabs DA, Nussenblatt RB, Rosenbaum JT (2005) Standardization of uveitis nomenclature for reporting clinical data. Results of the First International Workshop. Am J Ophthalmol 140:509-516

2. The World Health Report, WHO (2010) Global data on visual impairments. http://www.who.int/blindness/ GLOBALDATAFINALforweb.pdf. Accessed 21 Jan 2014

3. Nussenblatt RB (1990) The natural history of uveitis. Int Ophthalmol 14:303-308

4. Bodaghi B, Cassoux N, Wechsler B, Hannouche D, Fardeau C et al (2001) Chronic severe uveitis: etiology and visual outcome in 927 patients from a single center. Medicine (Baltimore) 80:263-270

5. Rothova A, Buitenhuis HJ, Meenken C, Brinkman CJ, Linssen A et al (1992) Uveitis and systemic disease. Br J Ophthalmol 76:137-141

6. Darrell RW, Wagener HP, Kurland LT (1962) Epidemiology of uveitis. Incidence and prevalence in a small urban community. Arch Ophthalmol 68:502-514

7. Suttorp-Schulten MS, Rothova A (1996) The possible impact of uveitis in blindness: a literature survey. Br J Ophthalmol 80:844-848

8. Grange LK, Kouchouk A, Dalal MD, Vitale S, Nussenblatt RB et al (2013) Neoplastic masquerade syndromes in patients with uveitis. Am J Ophthalmol. doi:10.1016/j.ajo.2013.11.002

9. Nussenblatt RB, Mittal KK, Ryan S, Green WR, Maumenee AE (1982) Birdshot retinochoroidopathy associated with HLA-A29 antigen and immune responsiveness to retinal S-antigen. Am J Ophthalmol 94:147-158

10. Kuiper JJ, Mutis T, de Jager W, de Groot-Mijnes JD, Rothova A (2011) Intraocular interleukin-17 and proinflammatory cytokines in HLA-A29-associated birdshot chorioretinopathy. Am J Ophthalmol 152:177-182, e171

11. Yang P, Foster CS (2013) Interleukin 21, interleukin 23, and transforming growth factor beta1 in HLA-A29-associated birdshot retinochoroidopathy. Am J Ophthalmol 156:400-406, e402

12. Agarwal RK, Silver PB, Caspi RR (2012) Rodent models of experimental autoimmune uveitis. Methods Mol Biol 900:443-469

13. Forrester JV, Klaska IP, Yu T, Kuffova L (2013) Uveitis in mouse and man. Int Rev Immunol 32:76-96

14. Chen J, Qian H, Horai R, Chan CC, Falick Y et al (2013) Comparative analysis of induced vs. spontaneous models of autoimmune uveitis targeting the interphotoreceptor retinoid binding protein. PLoS One 8:e72161

15. Mattapallil MJ, Silver PB, Mattapallil JJ, Horai R, Karabekian Z et al (2011) Uveitis-associated epitopes of retinal antigens are pathogenic in the humanized mouse model of uveitis and identify autoaggressive T cells. J Immunol 187:1977-1985

16. Caspi RR (2011) Understanding autoimmune uveitis through animal models. The Friedenwald Lecture. Invest Ophthalmol Vis Sci 52:1872-1879

17. Chu CJ, Herrmann P, Carvalho LS, Liyanage SE, Bainbridge JW et al (2013) Assessment and in vivo scoring of murine experimental autoimmune uveoretinitis using optical coherence tomography. PLoS One 8:e63002

18. Mackay LK, Wakim L, van Vliet CJ, Jones CM, Mueller SN et al (2012) Maintenance of T cell function in the face of chronic antigen 
stimulation and repeated reactivation for a latent virus infection. $\mathrm{J}$ Immunol 188:2173-2178

19. St. Leger AJ, Peters B, Sidney J, Sette A, Hendricks RL (2011) Defining the herpes simplex virus-specific $\mathrm{CD} 8^{+} \mathrm{T}$ cell repertoire in C57BL/6 mice. J Immunol 186:3927-3933

20. Wherry EJ, Blattman JN, Murali-Krishna K, van der Most R, Ahmed R (2003) Viral persistence alters CD8 T-cell immunodominance and tissue distribution and results in distinct stages of functional impairment. J Virol 77:4911-4927

21. Turner DL, Bickham KL, Thome JJ, Kim CY, D’Ovidio F et al (2013) Lung niches for the generation and maintenance of tissueresident memory T cells. Mucosal Immunol. doi:10.1038/mi.2013.67

22. Medawar PB (1948) Immunity to homologous grafted skin. 3. The fate of skin homografts transplanted to the brain, to subcutaneous tissue, and to the anterior chamber of the eye. Br J Exp Pathol 29: 58-69

23. Shechter R, London A, Schwartz M (2013) Orchestrated leukocyte recruitment to immune-privileged sites: absolute barriers versus educational gates. Nat Rev Immunol 13:206-218

24. Wraith DC, Nicholson LB (2012) The adaptive immune system in diseases of the central nervous system. J Clin Invest 122:1172-1179

25. Hickey WF (2001) Basic principles of immunological surveillance of the normal central nervous system. Glia 36:118-124

26. Engelhardt B, Ransohoff RM (2005) The ins and outs of Tlymphocyte trafficking to the CNS: anatomical sites and molecular mechanisms. Trends Immunol 26:485-495

27. Kivisäkk P, Mahad DJ, Callahan MK, Trebst C, Tucky B et al (2003) Human cerebrospinal fluid central memory $\mathrm{CD}^{+} \mathrm{T}$ cells: evidence for trafficking through choroid plexus and meninges via $\mathrm{P}$ selectin. Proc Natl Acad Sci U S A 100:8389-8394

28. Kerr EC, Raveney BJ, Copland DA, Dick AD, Nicholson LB (2008) Analysis of retinal cellular infiltrate in experimental autoimmune uveoretinitis reveals multiple regulatory cell populations. $\mathrm{J}$ Autoimmun 31:354-361

29. Correale J, Fiol M, Gilmore W (2006) The risk of relapses in multiple sclerosis during systemic infections. Neurology 67:652-659

30. Sherlock JP, Joyce-Shaikh B, Turner SP, Chao C-C, Sathe M et al (2012) IL-23 induces spondyloarthropathy by acting on ROR$\mathrm{\gamma t}^{+} \mathrm{CD}^{+} \mathrm{CD}^{-} \mathrm{CD}^{-}$entheseal resident T cells. Nat Med 18:10691076

31. Pepper M, Linehan JL, Pagan AJ, Zell T, Dileepan T et al (2010) Different routes of bacterial infection induce long-lived TH1 memory cells and short-lived TH17 cells. Nat Immunol 11:83-89

32. Bauer J, Bradl M, Hickey WF, Forss-Petter S, Breitschopf $\mathrm{H}$ et al (1998) T-cell apoptosis in inflammatory brain lesions - destruction of T cells does not depend on antigen recognition. Am J Pathol 153: $715-724$

33. Gold R, Hartung H-P, Lassmann H (1997) T-cell apoptosis in autoimmune diseases: termination of inflammation in the nervous system and other sites with specialized immune-defense mechanisms. Trends Neurosci 20:399-404

34. Copland DA, Liu J, Schewitz-Bowers LP, Brinkmann V, Anderson $\mathrm{K}$ et al (2012) Therapeutic dosing of fingolimod (FTY720) prevents cell infiltration, rapidly suppresses ocular inflammation, and maintains the blood-ocular barrier. Am J Pathol 180:672-681

35. Raveney BJ, Copland DA, Nicholson LB, Dick AD (2008) Fingolimod (FTY720) as an acute rescue therapy for intraocular inflammatory disease. Arch Ophthalmol 126:1390-1395

36. Wakim LM, Gupta N, Mintern JD, Villadangos JA (2013) Enhanced survival of lung tissue-resident memory $\mathrm{CD} 8^{+} \mathrm{T}$ cells during infection with influenza virus due to selective expression of IFITM3. Nat Immunol 14:238-245

37. Wakim LM, Woodward-Davis A, Bevan MJ (2010) Memory T cells persisting within the brain after local infection show functional adaptations to their tissue of residence. Proc Natl Acad Sci U S A 107:17872-17879
38. Sheridan BS, Lefrancois L (2011) Regional and mucosal memory T cells. Nat Immunol 12:485-491

39. Plumlee Courtney R, Sheridan Brian S, Cicek Basak B, Lefrançois L (2013) Environmental cues dictate the fate of individual CD8 ${ }^{+} \mathrm{T}$ cells responding to infection. Immunity 39:347-356

40. Anderson KG, Sung H, Skon CN, Lefrancois L, Deisinger A et al (2012) Cutting edge: intravascular staining redefines lung CD8 T cell responses. J Immunol (Baltimore Md: 1950) 189:2702-2706

41. Morrison SJ, Scadden DT (2014) The bone marrow niche for haematopoietic stem cells. Nature 505:327-334

42. Masters SL, Simon A, Aksentijevich I, Kastner DL (2009) Horror autoinflammaticus: the molecular pathophysiology of autoinflammatory disease. Annu Rev Immunol 27:621-668

43. Netea MG, van der Meer JWM (2011) Immunodeficiency and genetic defects of pattern-recognition receptors. N Engl J Med 364:60-70

44. Janssen CEI, Rose CD, De Hertogh G, Martin TM, Bader Meunier $\mathrm{B}$ et al (2012) Morphologic and immunohistochemical characterization of granulomas in the nucleotide oligomerization domain 2related disorders Blau syndrome and Crohn disease. J Allergy Clin Immunol 129:1076-1084

45. Kilmartin DJ, Wilson D, Liversidge J, Dick AD, Bruce J et al (2001) Immunogenetics and clinical phenotype of sympathetic ophthalmia in British and Irish patients. Br J Ophthalmol 85:281-286

46. Islam SM, Numaga J, Fujino Y, Hirata R, Matsuki K et al (1994) HLA class II genes in Vogt-Koyanagi-Harada disease. Invest Ophthalmol Vis Sci 35:3890-3896

47. Gocho K, Kondo I, Yamaki K (2001) Identification of autoreactive $\mathrm{T}$ cells in Vogt-Koyanagi-Harada disease. Invest Ophthalmol Vis Sci 42:2004-2009

48. Sugita S, Takase H, Taguchi C, Imai Y, Kamoi K et al (2006) Ocular infiltrating $\mathrm{CD}^{+}$T cells from patients with Vogt-Koyanagi-Harada disease recognize human melanocyte antigens. Invest Ophthalmol Vis Sci 47:2547-2554

49. Todd JA, Bell JI, McDevitt HO (1987) HLA-DQb gene contributes to susceptibility and resistance to insulin-dependent diabetes mellitus. Nature 329:599-604

50. Anderson AC, Nicholson LB, Legge KL, Turchin V, Zaghouani H et al (2000) High frequency of autoreactive myelin proteolipid protein-specific T cells in the periphery of naive mice: mechanisms of selection of the self-reactive repertoire. J Exp Med 191:761-770

51. Greter M, Heppner FL, Lemos MP, Odermatt BM, Goebels N et al (2005) Dendritic cells permit immune invasion of the CNS in an animal model of multiple sclerosis. Nat Med 11:328-334

52. Yosef N, Shalek AK, Gaublomme JT, Jin H, Lee Y et al (2013) Dynamic regulatory network controlling TH17 cell differentiation. Nature 496:461-468

53. Murphy KM, Stockinger B (2010) Effector T cell plasticity: flexibility in the face of changing circumstances. Nat Immunol 11:674-680

54. Murphy KM, Reiner SL (2002) The lineage decisions of helper T cells. Nat Rev Immunol 2:933-944

55. Caspi RR, Roberge FG, McAllister CG, el-Saied M, Kuwabara T et al (1986) $\mathrm{T}$ cell lines mediating experimental autoimmune uveoretinitis (EAU) in the rat. J Immunol 136:928-933

56. Caspi RR, Roberge FG, Chan CC, Wiggert B, Chader GJ et al (1988) A new model of autoimmune disease. Experimental autoimmune uveoretinitis induced in mice with two different retinal antigens. J Immunol 140:1490-1495

57. Chan C-C, Mochizuki M, Nussenblatt RB, Palestine AG, McAllister $\mathrm{C}$ et al (1985) T-lymphocyte subsets in experimental autoimmune uveitis. Clin Immunol Immunopathol 35:103-110

58. Rizzo LV, Silver P, Wiggert B, Hakim F, Gazzinelli RT et al (1996) Establishment and characterization of a murine $\mathrm{CD} 4^{+} \mathrm{T}$ cell line and clone that induce experimental autoimmune uveoretinitis in B10.A mice. J Immunol 156:1654-1660

59. Zhou R, Horai R, Silver PB, Mattapallil MJ, Zárate-Bladés CR et al (2012) The living eye "disarms" uncommitted autoreactive T cells 
by converting them to Foxp $3^{+}$regulatory cells following local antigen recognition. J Immunol 188:1742-1750

60. Lambe T, Leung JC, Ferry H, Bouriez-Jones T, Makinen $\mathrm{K}$ et al (2007) Limited peripheral T cell anergy predisposes to retinal autoimmunity. J Immunol 178:4276-4283

61. Foxman EF, Zhang M, Hurst SD, Muchamuel T, Shen D et al (2002) Inflammatory mediators in uveitis: differential induction of cytokines and chemokines in Th1- versus Th2-mediated ocular inflammation. J Immunol 168:2483-2492

62. Jager A, Dardalhon V, Sobel RA, Bettelli E, Kuchroo VK (2009) Th1, Th17, and Th9 effector cells induce experimental autoimmune encephalomyelitis with different pathological phenotypes. J Immunol 183:7169-7177

63. Luger D, Silver PB, Tang J, Cua D, Chen Z et al (2008) Either a Th17 or a Th1 effector response can drive autoimmunity: conditions of disease induction affect dominant effector category. J Exp Med 205:799-810

64. Peters A, Pitcher Lisa A, Sullivan Jenna M, Mitsdoerffer M, Acton Sophie E et al (2011) Th17 cells induce ectopic lymphoid follicles in central nervous system tissue inflammation. Immunity 35:986-996

65. McPherson SW, Yang J, Chan C-C, Dou C, Gregerson DS (2003) Resting CD8 $\mathrm{T}$ cells recognize $\beta$-galactosidase expressed in the immune-privileged retina and mediate autoimmune disease when activated. Immunology 110:386-396

66. Calder VL, Zhao ZS, Wang Y, Barton K, Lightman SL (1993) Effects of CD8 depletion on retinal soluble-antigen induced experimental autoimmune uveoretinitis. Immunology 79:255-262

67. Chen M, Copland DA, Zhao J, Liu J, Forrester JV et al (2012) Persistent inflammation subverts thrombospondin-1-induced regulation of retinal angiogenesis and is driven by CCR2 ligation. Am J Pathol 180:235-245

68. Kerr EC, Copland DA, Dick AD, Nicholson LB (2008) The dynamics of leukocyte infiltration in experimental autoimmune uveoretinitis. Prog Retin Eye Res 27:527-535

69. Forrester JV, Xu H, Kuffova L, Dick AD, McMenamin PG (2010) Dendritic cell physiology and function in the eye. Immunol Rev 234:282-304

70. Rao NA, Kimoto T, Zamir E, Giri R, Wang R et al (2003) Pathogenic role of retinal microglia in experimental uveoretinitis. Invest Ophthalmol Vis Sci 44:22-31

71. Dick AD, Carter D, Robertson M, Broderick C, Hughes E et al (2003) Control of myeloid activity during retinal inflammation. J Leukoc Biol 74:161-166

72. Banerjee D, Dick AD (2004) Blocking CD200-CD200 receptor axis augments NOS-2 expression and aggravates experimental autoimmune uveoretinitis in Lewis rats. Ocul Immunol Inflamm 12:115-125

73. Copland DA, Calder CJ, Raveney BJ, Nicholson LB, Phillips J et al (2007) Monoclonal antibody-mediated CD200 receptor signaling suppresses macrophage activation and tissue damage in experimental autoimmune uveoretinitis. Am J Pathol 171:580-588

74. Taylor N, McConachie K, Calder C, Dawson R, Dick A et al (2005) Enhanced tolerance to autoimmune uveitis in CD200-deficient mice correlates with a pronounced $\mathrm{Th} 2$ switch in response to antigen challenge. J Immunol 174:143-154

75. Carter DA, Dick AD (2004) CD200 maintains microglial potential to migrate in adult human retinal explant model. Curr Eye Res 28: 427-436

76. Dick AD, Broderick C, Forrester JV, Wright GJ (2001) Distribution of OX2 antigen and OX2 receptor within retina. Invest Ophthalmol Vis Sci 42:170-176

77. Wright GJ, Jones M, Puklavec MJ, Brown MH, Barclay AN (2001) The unusual distribution of the neuronal/lymphoid cell surface CD200 (OX2) glycoprotein is conserved in humans. Immunology 102:173-179

78. Wright GJ, Puklavec MJ, Willis AC, Hoek RM, Sedgwick JD et al (2000) Lymphoid/neuronal cell surface OX2 glycoprotein recognizes a novel receptor on macrophages implicated in the control of their function. Immunity 13:233-242

79. Hoek RM, Ruuls SR, Murphy CA, Wright GJ, Goddard R et al (2000) Down-regulation of the macrophage lineage through interaction with OX2 (CD200). Science 290:1768-1771

80. Preston S, Wright GJ, Starr K, Barclay AN, Brown MH (1997) The leukocyte/neuron cell surface antigen $\mathrm{OX} 2$ binds to a ligand on macrophages. Eur J Immunol 27:1911-1918

81. Broderick C, Hoek RM, Forrester JV, Liversidge J, Sedgwick JD et al (2002) Constitutive retinal CD200 expression regulates resident microglia and activation state of inflammatory cells during experimental autoimmune uveoretinitis. Am J Pathol 161:16691677

82. Horie S, Robbie SJ, Liu J, Wu WK, Ali RR et al (2013) CD200R signaling inhibits pro-angiogenic gene expression by macrophages and suppresses choroidal neovascularization. Sci Rep 3:3072

83. Cherwinski HM, Murphy CA, Joyce BL, Bigler ME, Song YS et al (2005) The CD200 receptor is a novel and potent regulator of murine and human mast cell function. J Immunol 174:1348-1356

84. Zhang S, Cherwinski H, Sedgwick JD, Phillips JH (2004) Molecular mechanisms of CD200 inhibition of mast cell activation. J Immunol 173:6786-6793

85. Jenmalm MC, Cherwinski H, Bowman EP, Phillips JH, Sedgwick JD (2006) Regulation of myeloid cell function through the CD200 receptor. J Immunol 176:191-199

86. Deckert M, Sedgwick JD, Fischer E, Schluter D (2006) Regulation of microglial cell responses in murine Toxoplasma encephalitis by CD200/CD200 receptor interaction. Acta Neuropathol 111:548558

87. Snelgrove RJ, Goulding J, Didierlaurent AM, Lyonga D, Vekaria S et al (2008) A critical function for CD200 in lung immune homeostasis and the severity of influenza infection. Nat Immunol 9:1074 1083

88. Caspi RR, Chan CC, Fujino Y, Najafian F, Grover S et al (1993) Recruitment of antigen-nonspecific cells plays a pivotal role in the pathogenesis of a T cell-mediated organ-specific autoimmune disease, experimental autoimmune uveoretinitis. J Neuroimmunol 47: $177-188$

89. Forrester JV, Huitinga I, Lumsden L, Dijkstra CD (1998) Marrowderived activated macrophages are required during the effector phase of experimental autoimmune uveoretinitis in rats. Curr Eye Res 17:426-437

90. Dick AD, Duncan L, Hale G, Waldmann H, Isaacs J (1998) Neutralizing TNF-alpha activity modulates T-cell phenotype and function in experimental autoimmune uveoretinitis. J Autoimmun $11: 255-264$

91. Dick AD, McMenamin PG, Korner H, Scallon BJ, Ghrayeb J et al (1996) Inhibition of tumor necrosis factor activity minimizes target organ damage in experimental autoimmune uveoretinitis despite quantitatively normal activated $\mathrm{T}$ cell traffic to the retina. Eur $\mathrm{J}$ Immunol 26:1018-1025

92. Hankey DJ, Lightman SL, Baker D (2001) Interphotoreceptor retinoid binding protein peptide-induced uveitis in B10.RIII mice: characterization of disease parameters and immunomodulation. Exp Eye Res 72:341-350

93. Calder CJ, Nicholson LB, Dick AD (2005) A selective role for the TNF p55 receptor in autocrine signaling following IFN-gamma stimulation in experimental autoimmune uveoretinitis. J Immunol 175:6286-6293

94. Raveney BJ, Copland DA, Calder CJ, Dick AD, Nicholson LB (2010) TNFR1 signalling is a critical checkpoint for developing macrophages that control of T-cell proliferation. Immunology 131: 340-349

95. Raveney BJ, Copland DA, Dick AD, Nicholson LB (2009) TNFR1dependent regulation of myeloid cell function in experimental autoimmune uveoretinitis. J Immunol 183:2321-2329 
96. Robertson MJ, Erwig LP, Liversidge J, Forrester JV, Rees AJ et al (2002) Retinal microenvironment controls resident and infiltrating macrophage function during uveoretinitis. Invest Ophthalmol Vis Sci 43:2250-2257

97. Dick AD, Forrester JV, Liversidge J, Cope AP (2004) The role of tumour necrosis factor (TNF-alpha) in experimental autoimmune uveoretinitis (EAU). Prog Retin Eye Res 23:617-637

98. Murphy CC, Greiner K, Plskova J, Duncan L, Frost A et al (2004) Neutralizing tumor necrosis factor activity leads to remission in patients with refractory noninfectious posterior uveitis. Arch Ophthalmol 122:845-851

99. Sharma SM, Nestel AR, Lee RW, Dick AD (2009) Clinical review: anti-TNFalpha therapies in uveitis: perspective on 5 years of clinical experience. Ocul Immunol Inflamm 17:403-414

100. Fordham JB, Hua J, Morwood SR, Schewitz-Bowers LP, Copland DA et al (2012) Environmental conditioning in the control of macrophage thrombospondin-1 production. Sci Rep 2:512

101. Tu Z, Li Y, Smith D, Doller C, Sugita S et al (2012) Myeloid suppressor cells induced by retinal pigment epithelial cells inhibit autoreactive T-cell responses that lead to experimental autoimmune uveitis. Invest Ophthalmol Vis Sci 53:959-966

102. Chen F, Hou S, Jiang Z, Chen Y, Kijlstra A et al (2012) CD40 gene polymorphisms confer risk of Behcet's disease but not of VogtKoyanagi-Harada syndrome in a Han Chinese population. Rheumatology 51:47-51

103. Copland DA, Wertheim MS, Armitage WJ, Nicholson LB, Raveney BJ et al (2008) The clinical time-course of experimental autoimmune uveoretinitis using topical endoscopic fundal imaging with histologic and cellular infiltrate correlation. Invest Ophthalmol Vis Sci 49:5458-5465

104. Zamiri P, Masli S, Kitaichi N, Taylor AW, Streilein JW (2005) Thrombospondin plays a vital role in the immune privilege of the eye. Invest Ophthalmol Vis Sci 46:908-919

105. Read RW, Szalai AJ, Vogt SD, McGwin G, Barnum SR (2006) Genetic deficiency of $\mathrm{C} 3$ as well as CNS-targeted expression of the complement inhibitor sCrry ameliorates experimental autoimmune uveoretinitis. Exp Eye Res 82:389-394

106. Read RW, Vogt SD, Barnum SR (2013) The complement anaphylatoxin receptors are not required for the development of experimental autoimmune uveitis. J Neuroimmunol 264:127-129

107. An F, Li Q, Tu Z, Bu H, Chan CC et al (2009) Role of DAF in protecting against T-cell autoreactivity that leads to experimental autoimmune uveitis. Invest Ophthalmol Vis Sci 50:3778-3782

108. Copland DA, Hussain K, Baalasubramanian S, Hughes TR, Morgan BP et al (2010) Systemic and local anti-C5 therapy reduces the disease severity in experimental autoimmune uveoretinitis. Clin Exp Immunol 159:303-314

109. Crane IJ, McKillop-Smith S, Wallace CA, Lamont GR, Forrester JV (2001) Expression of the chemokines MIP-1alpha, MCP-1, and RANTES in experimental autoimmune uveitis. Invest Ophthalmol Vis Sci 42:1547-1552

110. Hashida N, Ohguro N, Nishida K (2012) Expression analysis of cytokine and chemokine genes during the natural course of murine experimental autoimmune uveoretinitis. ISRN Inflamm a2012:471617

111. Keino H, Takeuchi M, Kezuka T, Yamakawa N, Tsukahara R et al (2003) Chemokine and chemokine receptor expression during experimental autoimmune uveoretinitis in mice. Graefes Arch Clin Exp Ophthalmol 241:111-115

112. Sonoda KH, Sasa Y, Qiao H, Tsutsumi C, Hisatomi T et al (2003) Immunoregulatory role of ocular macrophages: the macrophages produce RANTES to suppress experimental autoimmune uveitis. J Immunol 171:2652-2659

113. Su SB, Grajewski RS, Luger D, Agarwal RK, Silver PB et al (2007) Altered chemokine profile associated with exacerbated autoimmune pathology under conditions of genetic interferon-gamma deficiency. Invest Ophthalmol Vis Sci 48:4616-4625
114. Mandelcorn ED (2013) Infectious causes of posterior uveitis. Can J Ophthalmol 48:31-39

115. Khairallah M, Kahloun R (2013) Ocular manifestations of emerging infectious diseases. Curr Opin Ophthalmol 24:574-580

116. Dick AD, Siepmann K, Dees C, Duncan L, Broderick C et al (1999) Fas-Fas ligand-mediated apoptosis within aqueous during idiopathic acute anterior uveitis. Invest Ophthalmol Vis Sci 40:2258-2267

117. Denniston AK, Tomlins P, Williams GP, Kottoor S, Khan I et al (2012) Aqueous humor suppression of dendritic cell function helps maintain immune regulation in the eye during human uveitis. Invest Ophthalmol Vis Sci 53:888-896

118. Denniston AK, Kottoor SH, Khan I, Oswal K, Williams GP et al (2011) Endogenous cortisol and TGF-beta in human aqueous humor contribute to ocular immune privilege by regulating dendritic cell function. J Immunol 186:305-311

119. Forrester JV, Worgul BV, Merriam GR Jr (1980) Endotoxin-induced uveitis in the rat. Albrecht Von Graefes Arch Klin Exp Ophthalmol 213:221-233

120. Rosenbaum JT, McDevitt HO, Guss RB, Egbert PR (1980) Endotoxin-induced uveitis in rats as a model for human disease. Nature 286:611-613

121. Fox A, Hammer ME, Lill P, Burch TG, Burrish G (1984) Experimental uveitis. Elicited by peptidoglycan-polysaccharide complexes, lipopolysaccharide, and muramyl dipeptide. Arch Ophthalmol 102:1063-1067

122. Rosenzweig HL, Planck SR, Rosenbaum JT (2011) NLRs in immune privileged sites. Curr Opin Pharmacol 11:423-428

123. Gouveia EB, Elmann D, Morales MS (2012) Ankylosing spondylitis and uveitis: overview. Rev Bras Reumatol 52:742-756

124. Mielants H, Veys EM, Cuvelier C, De Vos M, Botelberghe L (1985) HLA-B27 related arthritis and bowel inflammation. Part 2. Ileocolonoscopy and bowel histology in patients with HLA-B27 related arthritis. J Rheumatol 12:294-298

125. Boyd SR, Young S, Lightman S (2001) Immunopathology of the noninfectious posterior and intermediate uveitides. Surv Ophthalmol 46:209-233

126. Jawad S, Liu B, Agron E, Nussenblatt RB, Sen HN (2013) Elevated serum levels of interleukin-17A in uveitis patients. Ocul Immunol Inflamm 21:434-439

127. Amadi-Obi A, Yu CR, Liu X, Mahdi RM, Clarke GL et al (2007) TH17 cells contribute to uveitis and scleritis and are expanded by IL-2 and inhibited by IL-27/STAT1. Nat Med 13:711-718

128. Martin DF, Chan CC, de Smet MD, Palestine AG, Davis JL et al (1993) The role of chorioretinal biopsy in the management of posterior uveitis. Ophthalmology 100:705-714

129. Whitcup SM, Chan CC, Li Q, Nussenblatt RB (1992) Expression of cell adhesion molecules in posterior uveitis. Arch Ophthalmol 110: $662-666$

130. Furusato E, Shen D, Cao X, Furusato B, Nussenblatt RB et al (2011) Inflammatory cytokine and chemokine expression in sympathetic ophthalmia: a pilot study. Histol Histopathol 26:1145-1151

131. Li Z, Liu B, Maminishkis A, Mahesh SP, Yeh S et al (2008) Gene expression profiling in autoimmune noninfectious uveitis disease. $\mathrm{J}$ Immunol 181:5147-5157

132. Nussenblatt RB (1991) Proctor lecture. Experimental autoimmune uveitis: mechanisms of disease and clinical therapeutic indications. Invest Ophthalmol Vis Sci 32:3131-3141

133. Oberg AL, Kennedy RB, Li P, Ovsyannikova IG, Poland GA (2011) Systems biology approaches to new vaccine development. Curr Opin Immunol 23:436-443

134. Ramsey SA, Gold ES, Aderem A (2010) A systems biology approach to understanding atherosclerosis. EMBO Mol Med 2:79-89

135. Manolio TA (2013) Bringing genome-wide association findings into clinical use. Nat Rev Genet 14:549-558

136. Wallace GR, Niemczyk E (2011) Genetics in ocular inflammationbasic principles. Ocul Immunol Inflamm 19:10-18 
137. Fei Y, Webb R, Cobb BL, Direskeneli H, Saruhan-Direskeneli G et al (2009) Identification of novel genetic susceptibility loci for Behcet's disease using a genome-wide association study. Arthritis Res Ther 11:R66

138. Remmers EF, Cosan F, Kirino Y, Ombrello MJ, Abaci N et al (2010) Genome-wide association study identifies variants in the MHC class I, IL10, and IL23R-IL12RB2 regions associated with Behcet's disease. Nat Genet 42:698-702

139. Mizuki N, Meguro A, Ota M, Ohno S, Shiota T et al (2010) Genome-wide association studies identify IL23R-IL12RB2 and IL10 as Behcet's disease susceptibility loci. Nat Genet 42:703-706

140. Kirino Y, Bertsias G, Ishigatsubo Y, Mizuki N, Tugal-Tutkun I et al (2013) Genome-wide association analysis identifies new susceptibility loci for Behcet's disease and epistasis between HLA-B*51 and ERAP1. Nat Genet 45:202-207

141. Hou S, Xiao X, Li F, Jiang Z, Kijlstra A et al (2012) Two-stage association study in Chinese Han identifies two independent associations in CCR1/CCR3 locus as candidate for Behcet's disease susceptibility. Hum Genet 131:1841-1850

142. Hou S, Yang Z, Du L, Jiang Z, Shu Q et al (2012) Identification of a susceptibility locus in STAT4 for Behcet's disease in Han Chinese in a genome-wide association study. Arthritis Rheum 64:4104-4113

143. Lee YH, Choi SJ, Ji JD, Song GG (2012) Genome-wide pathway analysis of a genome-wide association study on psoriasis and Behcet's disease. Mol Biol Rep 39:5953-5959

144. Cortes A, Hadler J, Pointon JP, Robinson PC, Karaderi T et al (2013) Identification of multiple risk variants for ankylosing spondylitis through high-density genotyping of immune-related loci. Nat Genet 45:730-738

145. Jostins L, Ripke S, Weersma RK, Duerr RH, McGovern DP et al (2012) Host-microbe interactions have shaped the genetic architecture of inflammatory bowel disease. Nature 491:119-124

146. Nair RP, Duffin KC, Helms C, Ding J, Stuart PE et al (2009) Genome-wide scan reveals association of psoriasis with IL-23 and NF-kappaB pathways. Nat Genet 41:199-204

147. Wei JC, Hsu YW, Hung KS, Wong RH, Huang CH et al (2013) Association study of polymorphisms rs4552569 and rs17095830 and the risk of ankylosing spondylitis in a Taiwanese population. PLoS One 8:e52801

148. Usui Y, Takeuchi M, Yamakawa N, Takeuchi A, Kezuka T et al (2010) Expression and function of inducible costimulator on peripheral blood CD4+ T cells in Behcet's patients with uveitis: a new activity marker? Invest Ophthalmol Vis Sci 51:5099-5104

149. Banchereau R, Cepika AM, Pascual V (2013) Systems approaches to human autoimmune diseases. Curr Opin Immunol 25:598-605

150. Okunuki Y, Usui Y, Takeuchi M, Kezuka T, Hattori T et al (2007) Proteomic surveillance of autoimmunity in Behcet's disease with uveitis: selenium binding protein is a novel autoantigen in Behcet's disease. Exp Eye Res 84:823-831

151. Ooka S, Nakano H, Matsuda T, Okamoto K, Suematsu N et al (2010) Proteomic surveillance of autoantigens in patients with Behcet's disease by a proteomic approach. Microbiol Immunol 54:354-361

152. Mao L, Yang P, Hou S, Li F, Kijlstra A (2011) Label-free proteomics reveals decreased expression of CD18 and AKNA in peripheral $\mathrm{CD}^{+} \mathrm{T}$ cells from patients with Vogt-Koyanagi-Harada syndrome. PLoS One 6:e14616

153. Candia J, Maunu R, Driscoll M, Biancotto A, Dagur P et al (2013) From cellular characteristics to disease diagnosis: uncovering phenotypes with supercells. PLoS Comput Biol 9:e1003215

154. Soon WW, Hariharan M, Snyder MP (2013) High-throughput sequencing for biology and medicine. Mol Syst Biol 9:640

155. Bendall SC, Simonds EF, Qiu P, el Amir AD, Krutzik PO et al (2011) Single-cell mass cytometry of differential immune and drug responses across a human hematopoietic continuum. Science 332: $687-696$
156. Bach JF (1997) Tolerance and uveitis. Am J Ophthalmol 123:684 687

157. Nussenblatt RB, Whitcup SM, de Smet MD, Caspi RR, Kozhich AT et al (1996) Intraocular inflammatory disease (uveitis) and the use of oral tolerance: a status report. Ann N Y Acad Sci 778:325-337

158. Thurau SR, Diedrichs-Mohring M, Fricke H, Burchardi C, Wildner G (1999) Oral tolerance with an HLA-peptide mimicking retinal autoantigen as a treatment of autoimmune uveitis. Immunol Lett 68: 205-212

159. Thurau SR, Wildner G (2003) An HLA-peptide mimics organspecific antigen in autoimmune uveitis: its role in pathogenesis and therapeutic induction of oral tolerance. Autoimmun Rev 2:171-176

160. Nussenblatt RB, Peterson JS, Foster CS, Rao NA, See RF et al (2005) Initial evaluation of subcutaneous daclizumab treatments for noninfectious uveitis: a multicenter noncomparative interventional case series. Ophthalmology 112:764-770

161. Sen HN, Levy-Clarke G, Faia LJ, Li Z, Yeh S et al (2009) High-dose daclizumab for the treatment of juvenile idiopathic arthritis-associated active anterior uveitis. Am J Ophthalmol 148(696-703):e691

162. Yeh S, Wroblewski K, Buggage R, Li Z, Kurup SK et al (2008) High-dose humanized anti-IL-2 receptor alpha antibody (daclizumab) for the treatment of active, non-infectious uveitis. J Autoimmun 31:91-97

163. Geri G, Terrier B, Rosenzwajg M, Wechsler B, Touzot M et al (2011) Critical role of IL-21 in modulating TH17 and regulatory T cells in Behcet disease. J Allergy Clin Immunol 128:655-664

164. Terrada C, Fisson S, De Kozak Y, Kaddouri M, Lehoang P et al (2006) Regulatory T cells control uveoretinitis induced by pathogenic Th1 cells reacting to a specific retinal neoantigen. J Immunol 176:7171-7179

165. Lee RW, Dick AD (2010) Treat early and embrace the evidence in favour of anti-TNF-alpha therapy for Behcet's uveitis. Br J Ophthalmol 94:269-270

166. Sugita S, Kawazoe Y, Imai A, Yamada Y, Horie S et al (2012) Inhibition of Th17 differentiation by anti-TNF-alpha therapy in uveitis patients with Behcet's disease. Arthritis Res Ther 14:R99

167. Commodaro AG, Peron JP, Lopes CT, Arslanian C, Belfort R Jr et al (2010) Evaluation of experimental autoimmune uveitis in mice treated with FTY720. Invest Ophthalmol Vis Sci 51:2568-2574

168. Ohno S, Nakamura S, Hori S, Shimakawa M, Kawashima H et al (2004) Efficacy, safety, and pharmacokinetics of multiple administration of infliximab in Behcet's disease with refractory uveoretinitis. J Rheumatol 31:1362-1368

169. Sugita S, Kawazoe Y, Imai A, Kawaguchi T, Horie S et al (2013) Role of IL-22- and TNF-alpha-producing Th22 cells in uveitis patients with Behcet's disease. J Immunol 190:5799-5808

170. Sugita S, Yamada Y, Kaneko S, Horie S, Mochizuki M (2011) Induction of regulatory $\mathrm{T}$ cells by infliximab in Behcet's disease. Invest Ophthalmol Vis Sci 52:476-484

171. Arida A, Fragiadaki K, Giavri E, Sfikakis PP (2011) Anti-TNF agents for Behcet's disease: analysis of published data on 369 patients. Semin Arthritis Rheum 41:61-70

172. Mesquida M, Molins B, Llorenc V, Hernandez MV, Espinosa G et al. (2013) Current and future treatments for Behcet's uveitis: road to remission. Int Ophthalmol

173. Perra D, Alba MA, Callejas JL, Mesquida M, Rios-Fernandez R et al (2012) Adalimumab for the treatment of Behcet's disease: experience in 19 patients. Rheumatology 51:1825-1831

174. Sfikakis PP, Theodossiadis PG, Katsiari CG, Kaklamanis P, Markomichelakis NN (2001) Effect of infliximab on sightthreatening panuveitis in Behcet's disease. Lancet 358:295-296

175. Cordero-Coma M, Yilmaz T, Onal S (2013) Systematic review of anti-tumor necrosis factor-alpha therapy for treatment of immunemediated uveitis. Ocul Immunol Inflamm 21:19-27

176. Kaufmann U, Diedrichs-Mohring M, Wildner G (2012) Dynamics of intraocular IFN-gamma, IL-17 and IL-10-producing cell 
populations during relapsing and monophasic rat experimental autoimmune uveitis. PLoS One 7:e49008

177. Commodaro AG, Bombardieri CR, Peron JP, Saito KC, Guedes PM et al (2010) p38a MAP kinase controls IL-17 synthesis in VogtKoyanagi-Harada syndrome and experimental autoimmune uveitis. Invest Ophthalmol Vis Sci 51:3567-3574

178. Zhang R, Qian J, Guo J, Yuan YF, Xue K (2009) Suppression of experimental autoimmune uveoretinitis by anti-IL-17 antibody. Curr Eye Res 34:297-303

179. Yoshimura T, Sonoda KH, Miyazaki Y, Iwakura Y, Ishibashi T et al (2008) Differential roles for IFN-gamma and IL-17 in experimental autoimmune uveoretinitis. Int Immunol 20:209-214

180. Peng Y, Han G, Shao H, Wang Y, Kaplan HJ et al (2007) Characterization of IL-17 $7^{+}$interphotoreceptor retinoid-binding protein-specific $\mathrm{T}$ cells in experimental autoimmune uveitis. Invest Ophthalmol Vis Sci 48:4153-4161

181. Chi W, Zhou S, Yang P, Chen L (2011) CD4 ${ }^{+} \mathrm{T}$ cells from Behcet patients produce high levels of IL-17. Eye Sci 26:65-69

182. Chi W, Zhu X, Yang P, Liu X, Lin X et al (2008) Upregulated IL-23 and IL-17 in Behcet patients with active uveitis. Invest Ophthalmol Vis Sci 49:3058-3064

183. Dick AD, Tugal-Tutkun I, Foster S, Zierhut M, Melissa Liew SH et al (2013) Secukinumab in the treatment of noninfectious uveitis: results of three randomized, controlled clinical trials. Ophthalmology 120:777-787

184. Martin TM, Zhang Z, Kurz P, Rose CD, Chen H et al (2009) The NOD2 defect in Blau syndrome does not result in excess interleukin-1 activity. Arthritis Rheum 60:611-618

185. Rosenzweig HL, Martin TM, Jann MM, Planck SR, Davey MP et al (2008) NOD2, the gene responsible for familial granulomatous uveitis, in a mouse model of uveitis. Invest Ophthalmol Vis Sci 49:1518-1524

186. Rosenzweig HL, Martin TM, Planck SR, Galster K, Jann MM et al (2008) Activation of NOD2 in vivo induces IL-1 beta production in the eye via caspase-1 but results in ocular inflammation independently of IL-1 signaling. J Leukoc Biol 84:529-536

187. Teoh SC, Sharma S, Hogan A, Lee R, Ramanan AV et al (2007) Tailoring biological treatment: anakinra treatment of posterior uveitis associated with the CINCA syndrome. Br J Ophthalmol 91:263-264
188. Kurz PA, Suhler EB, Choi D, Rosenbaum JT (2009) Rituximab for treatment of ocular inflammatory disease: a series of four cases. Br J Ophthalmol 93:546-548

189. Taylor SR, Salama AD, Joshi L, Pusey CD, Lightman SL (2009) Rituximab is effective in the treatment of refractory ophthalmic Wegener's granulomatosis. Arthritis Rheum 60: $1540-1547$

190. Tomkins-Netzer O, Taylor SR, Lightman S (2013) Can rituximab induce long-term disease remission in patients with intra-ocular non-infectious inflammation? Ophthalmologica 230:109-115

191. Atan D, Heissigerova J, Kuffova L, Hogan A, Kilmartin DJ et al (2013) Tumor necrosis factor polymorphisms associated with tumor necrosis factor production influence the risk of idiopathic intermediate uveitis. Mol Vis 19:184-195

192. Atan D, Fraser-Bell S, Plskova J, Kuffova L, Hogan A et al (2011) Punctate inner choroidopathy and multifocal choroiditis with panuveitis share haplotypic associations with IL10 and TNF loci. Invest Ophthalmol Vis Sci 52:3573-3581

193. Atan D, Fraser-Bell S, Plskova J, Kuffova L, Hogan A et al (2010) Cytokine polymorphism in noninfectious uveitis. Invest Ophthalmol Vis Sci 51:4133-4142

194. Atan D, Turner SJ, Kilmartin DJ, Forrester JV, Bidwell J et al (2005) Cytokine gene polymorphism in sympathetic ophthalmia. Invest Ophthalmol Vis Sci 46:4245-4250

195. Ramesh R, Kozhaya L, McKevitt K, Djuretic IM, Carlson TJ et al (2014) Pro-inflammatory human Th17 cells selectively express Pglycoprotein and are refractory to glucocorticoids. J Exp Med 211: 89-104

196. Lee RW, Creed TJ, Schewitz LP, Newcomb PV, Nicholson LB et al (2007) $\mathrm{CD} 4{ }^{+} \mathrm{CD} 25^{\text {int }} \mathrm{T}$ cells in inflammatory diseases refractory to treatment with glucocorticoids. J Immunol 179:7941-7948

197. Lee RW, Schewitz LP, Nicholson LB, Dayan CM, Dick AD (2009) Steroid refractory $\mathrm{CD}^{+} \mathrm{T}$ cells in patients with sight-threatening uveitis. Invest Ophthalmol Vis Sci 50:4273-4278

198. Schewitz LP, Lee RW, Dayan CM, Dick AD (2009) Glucocorticoids and the emerging importance of $\mathrm{T}$ cell subsets in steroid refractory diseases. Immunopharmacol Immunotoxicol 31:1-22

199. Chu CJ, Barker SE, Dick AD, Ali RR (2012) Gene therapy for noninfectious uveitis. Ocul Immunol Inflamm 20:394-405 